\title{
IMPROVING WRITING SKILL OF NARRATIVE TEXT BY USING SHORT VIDEO AT SMA NEGERI 1 SILAU KAHEAN
}

\author{
${ }^{1}$ Catri Novita F. Manalu, ${ }^{2}$ Natalia Widya Pasca Tarigan, \\ ${ }^{\mathbf{1}}$ Mila Kristi Sitopu, \& ${ }^{\mathbf{1}}$ Ayu Paulina Silaban \\ ${ }^{1}$ English Student, FKIP, University of Prima Indonesia \\ ${ }^{2}$ English Lecturer, FKIP, University of Prima Indonesia \\ Corresponding Author Email: catrinovitafranciska@gmail.com
}

\begin{tabular}{|c|c|}
\hline Article Info & Abstract \\
\hline $\begin{array}{l}\text { Article History } \\
\text { Received: February } 2021 \\
\text { Revised: March } 2021 \\
\text { Published: April } 2021\end{array}$ & $\begin{array}{l}\text { Video technology in ELT has been increasingly used to help students to improve } \\
\text { their language skills. Various videos are designed to present ELT materials. This } \\
\text { study aims to investigate the use of short videos to improve students'writing } \\
\text { skills of narrative texts at the senior high school. This study is categorized as }\end{array}$ \\
\hline $\begin{array}{l}\text { Keywords } \\
\text { Writing Skills; } \\
\text { Narrative Texts; } \\
\text { Short Videos; }\end{array}$ & $\begin{array}{l}\text { classroom action research. The data consist of qualitative and quantitative data. } \\
\text { The instruments used to attain the qualitative data are observation and } \\
\text { documentation, while the quantitative data are collected using writing tests. This } \\
\text { study is carried out in two cycles. The use of short videos helps students } \\
\text { understand the generic structures of narrative texts. During learning processes, } \\
\text { students are asked to analyze the narrative structures from the introductory to the } \\
\text { conclusion paragraph. The improvement of students' narrative texts is made in } \\
\text { the second cycle. The students' writing achievement is } 76.25 \text { in the second cycle. } \\
\text { The students' achievement achieves the passing grade. Therefore, the use of short } \\
\text { videos is able to improve students' writing skills of narrative texts at the senior } \\
\text { high school. }\end{array}$ \\
\hline
\end{tabular}

How to cite: Manalu, C. N. F., Tarigan, N. W. P., Sitopu, M. K., \& Silaban, A. P. (2021). Improving writing skill of narrative text by using short video at SMA Negeri 1 Silau Kahean, JOLLT Journal of Languages and Language Teaching, 9(2), 257-263, DOI: https://doi.org/10.33394/jollt.v\%vi\%i.3501

\section{INTRODUCTION}

Nowadays, in the modern era, technological sophistication and human resources are very influential, including language. Language is a communication system, sounds, words, and grammar used by people in certain regions or countries. Many languages are spread all over the world, and one of them is English. English, an international language, means everyone who wants to connect with other people from different countries uses English. In the world of education in Indonesia, English is taught both from elementary schools, junior high schools, high schools to tertiary institutions. Similar to Indonesian, which has four language skills, English also has four skills. The four skills in English are listening, speaking, reading, and writing (Uma \& Ponnambala, 2001). Every skill in English is interconnected. All of these skills are very important and must be mastered in English. However, in this study, the authors only focus on writing skills.

Students still have difficulty writing. Some of the factors that cause students to experience difficulty in writing are lack of vocabulary, the method of treatment provided is less attractive. Especially in the era of the Covid-19 pandemic, which made the learning system that was once face-to-face become courageous, so that students needed to learn online. Students also do not understand the use of grammar, word choice, use of tenses and sometimes hesitate when writing so that they cannot find ideas in writing. According to (Asmuti, 2002) by mastering writing skills, the writers can elaborate their ideas in a 
systematic arrangement. Students still have difficulty writing.In writing, students must look at the type of text to be written.

Researchers took several previous studies that in improving students 'narrative text writing skills using video by Fadila (2015). In her research, videos can improve students' writing skills in the narrative text through films. Films can improve writing narrative text skills. The results obtained from this study are the results of the post-test cycle 1 with a class average of 72.4. And the results of the post-test cycle II with an average of 83.1. Then by (Kristiani Vera Br Ginting et al., 2020), in their research, the result also shows that video can improve the writing skill of narrative text with the result in pre-test score 63.69, in the first post-test 72.50 and 78.02 in the second post-test. Then, Indasari (2010) also found improving students' writing skills of narrative texts by using short videos. The result shows that a short video can improve the writing skill of narrative text with the pre-test $68.22,7$ for the post-test in cycle 175.58 , and 78.31 for the post-test in cycle 2 .

There are many types of text in English, but the researchers only focused on narrative text in this research. The narrative text is text in the form of imaginary, true stories created by fairy tales, created by a person or group of people to entertain readers-for example, cinderella, snow white, fox and cat, and others. In classroom learning, teachers need media to deliver lessons to students. Lots of media are used in learning, but in this study, researchers will use video. The video used by researchers in this study is a video "The legend of Lake Toba." By using video, students understand better. The video uses audiovisual so that students will be interested in writing.

Based on the problem above, the researcher wants to conduct a research entitled "Improving Students' Writing Skill of Narrative Texts by Using Short Videos." This teaching-learning uses integrated teaching with focuses on teaching writing. The advantage of this research is that it is proven that the media increases students' curiosity to calculate everything that is on their minds. Especially in the era of the Covid-19 pandemic, this media can be applied to online and face-to-face meetings. The videos used do not have to be given face-to-face, but instead can be shared via class group and via zoom. The researcher in conducting the action put the target in SMA Negeri 1 Silau Kahean.

\section{RESEARCH METHOD \\ Research Design}

Research is an activity to find solutions to problems by gathering information and analyzing it systematically and objectively. The research design is a unitary, detailed, and specific plan for obtaining, analyzing, and interpreting data. Researchers in this study used classroom action research: identification, planning, action, observation, and reflection. The Source of data used in this study were students of SMA Negeri 1 Silau Kahean. There are nine classes in this school. Because there are so many populations, the researchers only choose one class used as a simple sample of the study. The class used in this study was class XI MIA 2, which consists of twenty students.

\section{Instruments}

Researchers provide training to students as an instrument in gathering information about their comprehension to write narrative text. In this study, researchers used qualitative and quantitative data instruments. The quantitative data were obtained, calculating the mean score of the test. The organization of sentences, structure, grammar, content, and understanding is part of the researchers' tests - the qualitative data from class observation, documentation. To analyze the quantitative data, the researchers used steps to collect the data, compare the students' scores, calculate the percentage of the students' scores, and conclude. 


\section{Data Analysis}

Data analysis techniques include planning, the researcher provides material, observation aids, and a sheet of test instruments used by researchers for the teaching and learning process. Action, at this stage, the researcher asks students to watch a short video then rewrite the story in their own words. Observations, this stage is carried out simultaneously with the implementation stage. Reflection, at this stage, the researcher observes whether the short video is successful or not. If it does not match the criteria, the researcher must revise the strategy and proceed to the second cycle. The researchers conducted by the researcher is in the form of grammar, understanding, content, and sentence structure. Five categories of assessing students' quantitative ability: excellent, good, poor, and fail. It can be presented in Table 1 as follows.

Table 1

Students' Achievement Category

\begin{tabular}{lll}
\hline Score & Category Ability & Ability \\
\hline $80-100$ & Excellent & Able \\
\hline $70-79$ & Good & Able \\
\hline $51-69$ & Poor & Unable \\
\hline O-50 & Fail & Unable \\
\hline
\end{tabular}

\section{RESEARCH FINDINGS AND DISCUSSION \\ Research Finding}

This study is classroom action research that consists of steps; planning, action, observation, and reflections (Kemmis \& Mc Taggart, 1999). Due to classroom action research, there some writing teaching-learning problems to be solved in this study. Before doing action activities, researchers identify writing problems. Then, the problems faced are solved using short videos.

\section{Identifying the problem}

After the researcher made observations, the researchers found several problems in writing narrative text skills in class XI MIA 2, namely there were 25\% who did not like writing English, $60 \%$ of the students were neutral, $15 \%$ liked writing English. According to students' opinions. As many as $75 \%$ of students still difficult to express their ideas in expressing their thoughts, and $25 \%$ of students easy to express their ideas/thoughts. All the students thought it took them a long time to write. After conducting the research, the researcher found problems that arose by students in the class. After doing the pre-test, the mean score of the students was 61.75. Based on the results of the pre-observation and pre-test conducted by the researchers, it can be seen that the writing ability of the eleventh-grade students at SMA Negeri 1 Silau Kahean is still low. This should be improved by applying teaching techniques. In the teaching and learning process, researchers used video to improve students' writing skills.

\section{Implementing Classroom Action Research Cycle 1}

This cycle is carried out in 2 meetings, namely face-to-face meetings and online meetings. In the first cycle, the researchers used planning, action, observation, and reflection. at the planning stage, the researchers prepare material from the internet. Researchers choose materials suitable for students. Researchers chose cartoon videos that were easy for students to understand. The title of the video used is "The Legend Of Lake Toba". The duration of this video is about 8 minutes. Next is the action stage. In this stage, the researchers applied teaching techniques using video. There are 2 meetings in this cycle. But it is divided into one face-to-face meeting and one online meeting. This is because of the anticipation of the 
prevention of the Covid-19 case. At the first meeting, the researcher conducted face-to-face research. First, the researchers gave a mask, greeted the students, and checked the attendance list of students. It didn't take long for researchers to prepare all the preparations for video playback using a laptop connected to the focus and speakers. Researchers show the video twice. After the video was shown, the researchers explained several important things in writing narrative text, such as the generic structure consisting of orientation, complications, and resolution. Then the researchers asked students to make paragraph text as an exercise in accordance with the structure of the narrative text.

Furthermore, at the second meeting, the researchers conducted online teaching using the zoom application. After all, students joined, the researcher began teaching by alluding to what had been explained in the previous meeting. After explaining, the researcher sent a video that was shown in class to a group of students via WhatsApp. After the students watched the video, the researchers asked the students to make conclusions from the story in narrative text using the generic structure and tenses described. Students finish writing. The researcher asks that the results of their writing be brought to a face-to-face meeting. After that, the researcher ended the teaching process by reminding us that there were still further meetings.

Then the observation stage, at the first meeting, all students take the class. In this meeting, students still have difficulty understanding the past tense. This is evidenced by an error when the researcher asked students to write down sentences in the past tense. They also lacked vocabulary. This was proven when there were still many students who asked researchers about vocabulary. At that time, many students made a noise because they borrowed dictionaries from each other. At the second meeting, not all students took the zoom class. In this meeting, students play an active role in research. Here the researcher asks students to watch the video that has been played. After watching the video, the researcher asked them to write the conclusion of the story in the form of narrative text.

Then the Reflection stage After analyzing the results of observations in cycle one, the researchers then reflected on studying the teaching and learning process he had been doing so far. Researchers Find Student Progress in Writing. The results of the observation showed that the students achieved improvement after taking action. In the first cycle, the students' average score increased. This can be seen by comparing the pre-test and post-test results during the implementation of the action. The final average score of students from the results of the posttest cycle I was 70.55. This is better than the mean pre-test score performed before the action, 61.75. However, in this cycle, the researchers still found some weaknesses in writing students' stories. Students have difficulty mastering vocabulary.

\section{Cycle 2}

In this cycle, the first stage is the plan. To overcome the weaknesses that appeared in cycle 1 , the researchers made a revision of the lesson plans in cycle 2 based on the results of observations and reflections from the teaching and learning process in cycle 1 . Because in the previous cycle, students still lacked vocabulary. In the material of cycle 2 , the researchers added some vocabulary exercises because of the results cycle 1, student still lacked vocabulary. In this cycle, the same as the first cycle, this second cycle also uses two meetings that are still focused on writing using the same video. The material used in this cycle is almost the same as the previous cycle.

Next stage of action, in the second cycle, the researchers applied the same techniques in teaching. There are two meetings in this cycle, one meeting via zoom and one meeting face to face. The Third Meeting was conducted online. Like the previous meeting, the researchers greeted students through the class WhatsApp group and provided a code that students would use to join the Zoom class. After all the students joined, the researchers began teaching by checking the attendance of the student. Then, the researchers touched on the teaching at the next meeting. The researchers then explain the narrative text, such as its understanding, the 
type of narrative text, its generic structure, and the tenses used in the narrative text. The researchers gave time and waited for the students to watch until it was finished. Then students write narrative text according to the narrative text structure.

Fourth meeting, this meeting is held face-to-face at school. Once the researchers enter the class, the researchers greet the students and check the student attendance list. The researchers began the lesson with several activities, such as collecting the results of writing narrative text that the students had done at home and asking questions about the narrative text. Then the researchers invited students to watch the video again. The video is still the same as the video that was played at the previous meeting. The researchers prepared everything to play the video-assisted by several students. The students are interested in watching the video. After completion, the researchers asked students to rewrite the video they watched into narrative text using a generic structure. All students finish writing, and the researchers ask students to collect their writing results.

Then Observation stage Third Meeting At the third meeting, not all students took the zoom class like the previous meeting. In this meeting, the researchers provided several guidelines in writing narrative text. Researchers provide some vocabulary to students related to the story. The fact is that students enthusiastically follow and respond to lessons during the learning process. Sometimes there are also students who joke in the learning process. Fourth Meeting, At this meeting, all students were present to actively participate in the research. When the video is playing, all students pay attention to the video. Some students seemed to protest by showing expressions of not wanting to write anymore, but they did it even though they were a little forced. While writing, several students ask each other about their writing. Some are busy borrowing dictionaries and so on. Active class until the meeting is over.

Reflection stage In cycle 2, the researchers found several improvements. So that students are motivated and interested in the teaching and learning process. They are also more confident in writing individually after watching the video. They also find it easier to develop their ideas. There have also been some improvements in students' writing skills. Students are better able to use past sentences correctly. In addition, the test scores in cycle 2 showed an increase in results. The average pre-test score in cycle 2 was 61.75 , while the average posttest score in cycle 1 was 70.55, and the average post-test score in cycle 2 was 76.25. The graduation of students' writing skills of narrative texts can be presented in Figure 1 as follows.

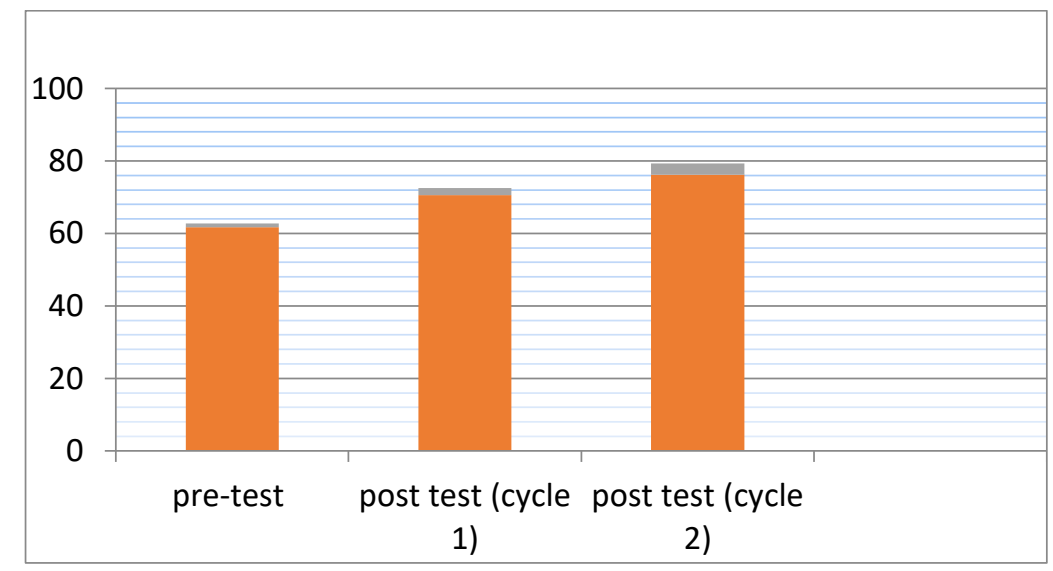

Figure 1. Students' Writing Skills 


\section{Discussion}

From the research results, short videos can improve students' ability to write narrative text. Short videos can stimulate students to make narrative easier because they can visualize the storyline and then write them down on paper. Teachers very effectively use this method because learning to write is not monotonous and makes students not feel bored (Rahman \& Tarbiyah, 2020). Students also became more confident in writing after watching the video. The students also find it easier to develop their ideas. Students are better able to use sentences in the past tense correctly. It is in line with Miner and Stefaniak (2018), who inform that the use of video in instruction can encourage students to accomplish their learning tasks.

During the learning process, students are provided with writing exercises. In pairs, students discuss the writing topics going to write. When students face difficulties understanding the topic, students are asked to watch videos relating the topic. In addition, students also are provided with videos containing generic structures of the narrative text. Students need to keep going with their writing exercises. It is in accordance with Faridha (2019); Haerazi et al. (2020) who argues that videos are very helpful for students to reconstruct their knowledge of topics going to write because the videos can be designed in the form of auditory and visual clues.

In this study, researchers used two cycles. In the first cycle, the researchers carried out the fourth stage, namely planning, action, observation, and reflection. In the planning stage, the researcher prepared everything needed in the research. Then, action is carried out. At this stage, the researchers taught by providing material and displaying the short video face to face and online (Widodo, 2016). The next step is observation. At this stage, the researchers observe students during the learning process. The last one is reflection. At this stage, the researchers find the results of the students' writing ability. In the results found by researchers in this cycle, there were some students who still had difficulty writing narrative text. This was evidenced by the results of the tests carried out. There were still many errors in the use of tenses, generic structures, and lack of vocabulary.

Then in the second cycle, the researcher also used the fourth stage as in the previous cycle. In this cycle, the student's ability to write narrative text had increased compared to that in the first cycle. This is evidenced by the use of tenses. The generic structure in this cycle is much better. From the test results starting from the pre-test, the mean score of students was 61.75, which increased when the video was given, wherein the post-test 1 , the average score increased to 70.55, and in the post-test 2, the average score became 76, 25 This means that the use of short videos as props can improve students' ability in writing narratives. Short videos are one of the learning media that is very effective in the learning process, especially during the Covid 19 pandemic that we are facing today. This is evident because short videos can be used in face-to-face and online learning.

\section{CONCLUSION}

Based on the findings above, the researchers concluded that teaching writing using short videos as media could improve students' writing skills. The students become easier to generate and organize ideas as their writers. The videos that the students watch can provide students with specific topics. The students can write scene by scene in the video so that they will produce systematic writing according to the structure of the narrative text from start to finish. By using short videos in writing classes, students are more motivated to join writing classes. The video features an interesting and audible moving image so they can relax before writing a story. The use of audiovisual methods, it can generate enthusiasm for students to develop their writing. 


\section{ACKNOWLEDGEMEN}

We would like to praise and thank God for the helping and blessing that he had given to us to finalize the thesis entitled "improving writing skill of narrative text by using short video at Sma Negeri 1 Silau Kahean". Researchers this thesis is proposed as one of the requirements in complementing the undergraduate program (s1) English education study program.

\section{REFERENCES}

Anggraini, Y. A., Yasin \& Desmawati, R. (2014). Improving Students' Writing Skill of Narrative Text Through Video at Grade XII IPA 2 of SMAN 2 Bukit Tinggi. Journal English Language Teaching, 2(2), 78-92.

Agusta, D. (2015). Improving Students' Ability in Writing Narrative Texts Using Short Animated Stories at Class VIII C of SMPN 2 Sanden, Bantul in the Academic Year of 2013/2014. Core.Ac.Uk.

Faridha, N. (2019). The Effect of Video in Teaching Writing Skill across Different Personality. JEES (Journal of English Educators Society), 4(1), 61. https://doi.org/10.21070/jees.v4i1.1808

Ginting, K. L. V, Dinda. S \& Cahaya. R, Nita. P \& Sri Ninta. T. (2019). Improving Students' Skill in Writing Narrative Text Through Animation Movie. Linguistic, English $\begin{array}{llll}\text { Education Art } & \text { (LEEA) Journal, 3(1), 230-237 }\end{array}$ https://doi.org/https://doi.org/10.31539/leea.v3i1.1000

Haerazi, H., Utama, I. M. P., \& Hidayatullah, H. (2020). Mobile Applications to Improve English Writing Skills Viewed from Critical Thinking Ability for Pre-Service Teachers. International Journal of Interactive Mobile Technologies (IJIM), 14(07), 58. https://doi.org/10.3991/ijim.v14i07.11900

Hamzah, A. (2016). The Use of Videos to Improve Students' Writing Skill on Narrative Text in English Learning Process. Jurnal Nalar Pendidikan, 4(2), 137-143.

Indasari, N. (2010). Improving Students' Writing Skill of Narrative Texts by Using Short Videos. Journal Publication Universitas Islam Negeri Raden Intan Lampung.

Martono, R. D. A, Abdul. A \& Muh. Asrori. (2001). Improving Students' Skill in Writing Narrative Text Through Animation Movies. FKIP UNS Journal Systems, 2(3), 402-409.

Merindriasari, K. Iwan, S \& Wardah. (2015). The Use of Animated Short Film as Media for Teaching English Narrative Writing. Jurnal Ilmiah Universitas Tanjung Pura, 4(2), 19.

Miner, S., \& Stefaniak, J. E. (2018). Learning via Video in Higher Education : An Exploration of Instructor and Student Perceptions Learning via Video in Higher Education: An Exploration of Instructor and. Journal of University Teaching and Learning Practice, 15(2). http://ro.uow.edu.au/jutlp/vol15/iss $2 / 2$

Rahman, M. A., \& Tarbiyah, F. (2020). The Use of the ASSURE Model in Developing Animation Video as English Teaching Materials for Islamic Kindergarten Students. International Journal of Innovation, Creativity and Change, 11(10), 1-19.

Warni, J. (2018). The Use of Islamic History Videos through Swell Strategy to Improve Senior High Students ' Narrative Writing Achievement. Jurnal Pendidikan Dan Pengajaran, 5(1), 53-62.

Wattini. (2016). Using Short Video to Improve the Students' Writing in Narrative Text at the Eighth Grade of MTS AR-Roudhloh Pajaran. Jurnal Ilmiah Edukasi \& Sosial, 7(1), 7580 .

Widodo, H. P. (2016). Engaging Student Teachers in Collaborative and Reflective Online Video-Assisted Extensive Listening in an Indonesian Initial Teacher Education ( ITE ) Context. Electronic Journal of Foreign Language Teaching, 13(2), 229-244. 